\title{
Organic amendments as sustainable tool to recovery fertility in intensive agricultural systems
}

\author{
R. Scotti ${ }^{*}$, G. Bonanomi ${ }^{2}$, R. Scelza ${ }^{2}$, A. Zoina ${ }^{2}$, M.A. Rao ${ }^{2}$ \\ ${ }^{1}$ Consiglio per la ricerca in agricoltura e l'analisi dell'economia agraria, Centro di Ricerca per l'Orticoltura, \\ Via dei Cavalleggeri 25 - 84098 Pontecagnano (SA), Italy. *Corresponding author: riccardo.scotti@entecra. \\ it ${ }^{2}$ Dipartimento di Agraria, Università degli Studi di Napoli Federico II, Via Università 100 - 80055 Portici \\ (NA), Italy.
}

\begin{abstract}
Intensive agriculture is a farming system characterised by a large use of inputs, causing a large pressure on the environment. As peculiar and efficient example of intensive agriculture cultivation under plastic tunnels provides several advantages for farmers due to improvement of microclimatic conditions coupled with a relatively low investment costs. In the Mediterranean Basin such cultivation systems reach about 200,000 ha mainly in Spain, Turkey, Italy, and Morocco. As downside, intensive agriculture negatively affects soil fertility principally because of a loss in soil organic matter. Sustainable practices providing organic amendments could be a useful tool to maintain or increase organic matter content in agricultural soils, preserving and improving soil fertility. An improved knowledge of management factors affecting soil quality is crucial to plan farming systems that effectively maintain soil fertility. Therefore, this review focuses on the potential value of organic amendments in the recovery of soil fertility, in particular in sites under plastic cover intensive farming system. Following a brief overview of the effects of intensive agriculture on soil, the review describes various organic amendments used in agriculture and their benefits on soil fertility, to conclude with the need, in the future researches, to identify organic amendments able to maximize a recovery of soil fertility.
\end{abstract}

Keywords: Compost; plastic cover, soil quality, soil organic carbon, enzymatic activities, plant disease suppression

\section{Introduction}

Agriculture has been capital for the development of human civilization, thank to the agriculturalists that have been the chief managers of terrestrial 'useable' lands, shaping and changing the land around us. Before agriculture developing, the hunter-gatherer lifestyle supported about 4 million people globally, whereas today modern agriculture feeds 7,300 million people (Tilman et al., 2002; Worldometers, 2015) but at the expense of ecosystem health. Agricultural practices, based on large application 
of fertilizers and pesticides, reduce the ability of ecosystems to provide goods and services. In fact, the increasing risk of contamination from nutrients and toxic chemical compounds occurs in groundwater and surface waters, incurring in eutrophication and soil quality degradation (Tilman et al., 2002). This incorrect agricultural management can change species composition or reduce biodiversity in ecosystems thus affecting natural abilities of ecosystems (Hector et al., 1999; Loreau et al., 2001).

As reported by Tilman et al. (2002), the global use of nitrogen $(\mathrm{N})$ and phosphorus fertilizers increased by 7 and 3.5 fold, respectively, in the past six decades; both fertilizers are expected to increase further threefold by 2050 , featuring a conversion of agricultural practices more and more towards intensive agriculture systems. Intensive agriculture is a farming system characterised by a large use of capital and inputs to invest in the acquisition and application of fertilizers and pesticides necessary to crop growing (Eurostat, 2015). The abundant use of fertilizers and pesticides also increases the risk that nutrients and pesticides run-off into surface and leach into groundwater (Eurostat, 2015).

In the last 15 years, literature about intensive agriculture considerably increased thus indicating a strong interest of researchers to this topic from different points of view (Figure 1a). Indeed, the word cloud illustrated in Figure 1b, shows that the word "soil" has the highest frequency among all these publications, highlighting the key role of the soil in this issue and stressing the idea that the soil is the sink where more than other the intensive agriculture causes negative effects.

Soil is a dynamic natural system that lies at the interface between earth, air, water, and life, providing critical ecosystem service for the sustenance of humanity (Needelman, 2013). Preservation of soil quality is among the great challenges and opportunities we have to face in the $21^{\text {st }}$ century. Soil quality is usually defined as the capacity of soil to interact with the ecosystem in order to maintain the biological productivity, the quality of other environmental compartments, thus promoting the health of plants and animals, including humans (Doran and Parkin, 1994). Soil quality may quickly deteriorate because of intensive management, stabilize with time under proper management, and improve in the long time by supplying of organic matter. Decline in soil organic matter under intensive farming systems is a major cause of soil fertility loss. Organic matter plays a critical role in soil ecosystem because it provides substrates for decomposing microbes (that in turn supply mineral nutrients to plants), improves soil structure and water holding capacity (Abiven et al., 2009), increases natural suppressiveness against soil-borne pathogens (Bonanomi et al., 2010), and reduces heavy metal toxicity (Park et al., 2011). In this scenario, a recovery of depleted soil organic matter and its maintenance to an adequate level is a critical task. It has been shown that application of organic amendments such as compost is a reliable and effective tool to ameliorate soil structure and both chemical (Scotti et al., 2013) and biological fertility of soils (Ros et al., 2003), as well as to suppress soilborne pathogens (Zaccardelli et al., 2013a).

Therefore, this review focuses on the potential value of organic amendments in the recovery of soil fertility, in particular in sites under plastic cover intensive farming system. Following a brief overview of intensive agriculture effects on soil and on the cycles of the main nutrients, the review describes the various organic amendments used in agriculture and their benefits on the main properties of soils under intensive farming. Increasing interest arises in identifing specific organic amendments that can maximize the stable soil organic carbon (C) recovery, with an improvment of soil fertility, and, at the same time, allow a sufficient release of 
mineral nutrients to sustain crop yields, in a sustainable agricultural management.

\section{Intensive agricultural systems: a thorny problem}

Intensive cultivation under plastic tunnels provides several advantages for farmers due to the improvement of microclimatic conditions and relatively low investment costs. In fact, protected cultivation can reduce the resource input (irrigation water, fertilizers and pesticides) compared with open filed, coupled with higher crop yields that can translate in high net income for farmers (Lamont, 2009). As a consequence, cultivation under plastic tunnels is a growing agricultural sector (ScarasciaMugnozza et al., 2011). China alone account for more than 2,500,000 ha of greenhouse, while in the Mediterranean Basin such cultivation systems reach $\sim 200,000$ ha mainly in Spain, Turkey, Italy, and Morocco (Pardossi et al., 2004).

However, several concerns developed with the longterm sustainability of this farming system, especially in relation to soil quality management. Cultivation under plastic cover is expected to profoundly affect soil quality because it dramatically alters water, organic $\mathrm{C}$ and nutrient cycles (Figure 2). In fact, natural rainfall is almost completely restricted under plastic tunnels and the consequent requirement of irrigation to sustain crop water demand increases soil salinity in superficial soil layers. In this regards, a number of recent studies highlighted that vegetable cultivation under plastic tunnel can, in the long-term, negatively affect soil quality, resulting in a decline of crop yields. A recent survey carried out in southern Italy (Bonanomi et al., 2011a) found that continuous cultivation for 20 years under plastic tunnels increased soil salinity and, at the same time, provoked a steep decline in organic C stocks. Similar results were reported for cultivation under tunnels in China (Chen et al., 2004; Ju et al., 2007) where a steep increase of salinity occurred coupled with soil acidification that was likely caused by mineral fertilization overuse.

A deep knowledge of environmental factors that affect soil quality is crucial for planning farming systems focused to effectively maintain soil quality. In literature, it is widely reported that intensive cultivation regime under plastic cover produces significant increase in soil salinity, acidification, reduction of organic $\mathrm{C}$ stock and stoichiometric imbalance among main nutrients, demonstrating a consistent trend of soil quality loss in agreement with the common view that intensive agricultural management decreases soil quality (Mäder et al., 2002).

\subsection{Effects on the main nutrients cycle}

Maintenance of an adequate organic $\mathrm{C}$ stock in agricultural soils is of primary importance for nutrient supplying, (Tian et al., 1992), for improving soil structure (Abiven et al., 2009), sustaining microbial activities (Mäder et al., 2002), and maintaining suppressiveness against soil-borne pathogens (Bonanomi et al., 2010). However, under intensive agriculture systems soil organic C stock declines (Halvorson et al., 2002; Knops and Tilman 2000) and cultivations under plastic tunnels are not an exception (Bonanomi et al., 2011a).

Soil organic $\mathrm{C}$ depletion can be related to an imbalance between the amount of organic matter inputs compared to the amount of organic $\mathrm{C}$ outflows, mainly regulated by temperature and water availability. Moreover, under plastic tunnels crop residues are not incorporated into the soil at the end of cultivation, but systematically removed to limit phytopathological problems (Agrios, 2005). The limited fraction of plant debris that is integrated into the soil (e.g. root exudates, death roots and a certain fraction of leaf litter) has, however, a high organic $\mathrm{C}$ biochemical quality in terms of low lignin content coupled with abundant labile $\mathrm{C}$ fraction and low $\mathrm{C} / \mathrm{N}$ ratio. This kind 
of plant tissues rapidly degrades and almost disappears, often within few months, when incorporated into the soil (Bonanomi et al., 2013) and this organic input provides only a rather marginal contribution for the maintenance of soil organic C stock. Moreover, the supply of plantderived organic $\mathrm{C}$ with high biochemical quality can stimulated the microbial mineralization of more stable and recalcitrant soil organic $\mathrm{C}$ fractions through priming effect (Fontaine et al., 2007).

Organic $\mathrm{C}$ outflows are especially intense in soils cultivated under plastic cover. Rapid organic C mineralization occurs because of i) the enhanced soil temperatures, ii) the constant supply of irrigation water also in dry summer months and, iii) the careful avoidance of soil water logging that provides the optimal environmental conditions to allow soil microbial and fungal activities (Aerts, 1997).

The intensive tillage regime promotes organic $\mathrm{C}$ mineralization by favouring gas exchanges among different soil layers (Paustian et al., 2000). Bonanomi et al. (2011a) reported that in southern Italy vegetable cultivation under plastic tunnel requires, in average, 6.05 tillage treatments every year with rototilling, spading and harrowing as the most common practices. In addition, the continuous supply of mineral nutrients by fertigation promotes microbial decomposition of plant tissues with low $\mathrm{N}$ content (Bonanomi et al., 2014a; Xiong et al., 2014).

An immediate consequence of the depletion of organic $\mathrm{C}$ stock is the reduction of soil $\mathrm{C} / \mathrm{N}$ ratio. This effect is often exacerbated by the plenty amount of $\mathrm{N}$ provided as fertilizer, in both organic and inorganic forms (Chen et al., 2004). In some cultivation systems very low soil $\mathrm{C} / \mathrm{N}$ ratio has been reported, with values ranging from 3 to 6 (Bonanomi et al., 2011a). Such values are considered extremely low compared with that normally reported for agricultural soils ( 10) (Batjes, 1996), which indicates that both $\mathrm{C}$ and $\mathrm{N}$ cycles under intensive land use are deeply altered. Long-term soil cultivation under permanent plastic cover reduces, indeed, organic $\mathrm{C}$ stock, impairs the stoichiometric balance between organic $\mathrm{C}$ and $\mathrm{N}$ and, as a consequence, contributes to the decline of soil quality.

Under this scenario, recovery and subsequent maintenance of an adequate soil organic $\mathrm{C}$ stock are a priority to sustain high and long-term crop yields. Farmers who adopt this agricultural system are aware of this problem and they commonly try to compensate soil organic $\mathrm{C}$ loss through organic amendments.

\section{Sources and types of organic amendments}

The use of organic amendments to improve soil quality and fertility dates back to thousands of years ago. Greeks and Romans applied animal manure and human sewage to soil. At that time they also knew that wheat took advantages if grown on fields previously cultivated with leguminous plants (Goss et al., 2013). Different materials, such as sea-shells, vegetable waste, farmyard manure and other waste products were already used to promote crop growth.

Nowadays the most common soil organic amendments are compost and animal manure, but also peat moss, wood chips, straw, sewage sludge, sawdust are used. The different materials can be grouped essentially in five categories (Goss et al., 2013).

1. Animal manure. Manure is composed by faeces, urine and animal bedding stacked and turned until a certain level of composting. It derives from beef, dairy, pork, poultry, and turkey, and its composition depends on its origin, the time that urine and faeces are excreted and mixed and the storage time before being applied to soil. Manure supplies nutrients for crops but also organic matter thus improving soil fertility (Goss et al., 2013). Indeed, the degradation processes occurring in the surface layers of the manure, under aerobic conditions, produce $\mathrm{CO}_{2}$ and not easily degradable organic compounds; conversely, 
when anoxic conditions occur, mainly in the deeper layers of manure if it is not turned, small molecules of volatile organic acids and $\mathrm{CH}_{4}$ gas form.

2. Municipal biosolids. Municipal sludge or biosolids are organic solids subjected to several treatments to stabilize organic matter in order to reduce unpleasant smell and not attract pests and spreading disease (Goss et al., 2013). As containing nutrients and organic matter, biosolids can be applied to agricultural soils but under regulatory controls that set limits for heavy metals, weeds, human and plant pathogens.

3. Green manure and cover crops. Green manure consists in incorporating into the soil specific forage or crop varieties while green or soon after flowering to improve soil physical and chemical fertility (Goss et al., 2013). Cover crops can be useful in crop rotations also to fill in short period of non-cultivation to protect soils, prepare land for a perennial crop or provide animal feed. Cereal crops contribute with straw remained after harvest, whereas legumes, such as soybeans, cowpeas, clover, are frequently preferred as they are able to fix $\mathrm{N}$ from atmosphere working with bacteria at root level. As green manure legumes are useful to add $\mathrm{N}$ besides organic matter that soil gains when whole plants are buried. Even non-legumes plants, such as forage sorghum, millet, annual ryegrass, buckwheat, are used to provide biomass and suppress weeds. The main benefit of green manure and cover crop is the addition of nutrients and organic matter to the soil, but also an increase in microbial activity and water retention capability. Independently of its incorporation into the soil, a cover crop is any crop grown to provide soil cover and to prevent erosion by wind and water (Sullivan, 2003). For example, planting cover crop in the late summer or fall help soil to be protected during the winter. A summer cover crop will enhance the poor soils or prepare soil for a perennial crop (Sullivan, 2003).
4. Waste from manufacturing processes. Several organic by-products coming from manufacturing processes such as exhausted seeds, hoof and horn meal, animal feathers and fur, residues from sugar extraction, biochar, distillery waste, biosolids from paper mill can be applied to soil (Goss et al., 2013). In the latter case, only a small fraction is used for agronomic purpose because not enough information is available about lignin mineralization during composting (Tuomela et al., 2000; Goss et al., 2013).

5. Compost. Decomposition of organic wastes leads to the formation of the most used soil amendment, the compost. The use of compost represents both an interesting agricultural practice and a waste recycling management (Pérez-Piqueres et al., 2006). Indeed, it allows reducing the costs of green/urban waste disposal, recycling nutrient elements for crops and providing for soil organic matter depletion. Multiple benefits derive from the use of compost as fertilizer, for example an increase in organic $\mathrm{C}$ content and microbial activity (Scotti et al., 2015), a greater concentration of plant nutrients like $\mathrm{N}, \mathrm{P} \mathrm{K}$ and $\mathrm{Mg}$, and a root reinforcement (Donn et al., 2014). The improving of soil porosity with a consequent increase of water available for plants (Scotti et al., 2013), cation exchange capacity (CEC), and biological activities can also occur. An important feature of compost is the capability to influence soil microflora by suppressing many soilborne pathogens diseases such as Pythium, Phytophthora, Fusarium spp. (Szczech and Smolińska, 2001; Borrero et al., 2004). In the last years, the use of commercial compost in agriculture has been replaced by on-farm compost. On-farm composting could be an efficient, costeffective and environmentally safe biological process for the recycling of residual agricultural biomasses (Pane et al., 2015). In this way, the on-farm compost production could contribute to solve the problem of disposing agricultural biomasses and vegetable 
feedstock and, at the same time, to provide for farmers a self-supply of quality compost for the improvement of soil quality.

\section{Benefits of organic amendment use in intensive agriculture}

Soil management under intensive agriculture needs complex and appropriate practices and all efforts must be made to efficiently contrast soil degradation due to stress conditions of this management. A wide array of organic amendments, having different levels of processing are used. Composts are most frequently used to increase soil organic $\mathrm{C}$ stock, provide essential nutrients (such as $\mathrm{N}$ and $\mathrm{P}$ ) and improve microbial populations and activities (Figure 3 ). In this section benefits of organic amendments in intensive agriculture systems in terms of enhancing soil quality (physical, chemical and biological fertility) and improving crops yields and disease suppressivity will be discussed.

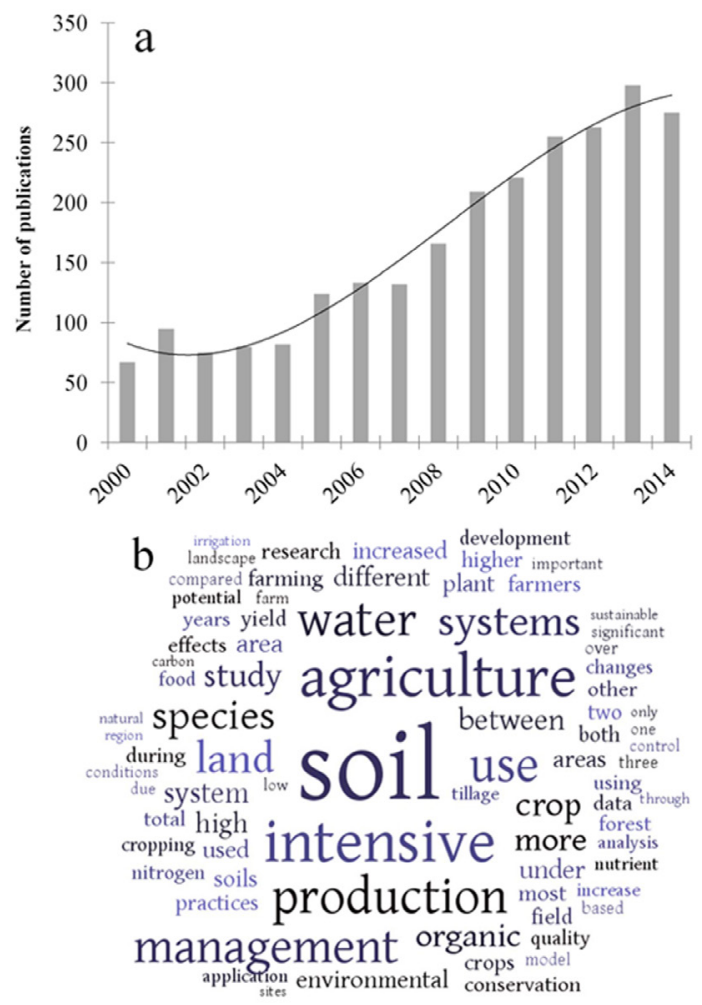

Figure 1. Panel a: Results of the search performed on Scopus on March, 2015 sorted by typing 'intensive agriculture' in the article title, abstract and keyword fields, in the subject area "life sciences (agricultural and biological sciences; environmental science)". Panel b: Word cloud performed on the basis of Scopus results. The size of each word is proportional to the overrepresentation of this term in the text. The text is composed by titles, abstracts and keywords obtained from the search performed on Scopus on March, 2015 and submitted to the online cloud generating software "Word It Out" (http://www. worditout.com). The entry words are placed in order of count, for a total number of 70 words and a minimum count of 599. 


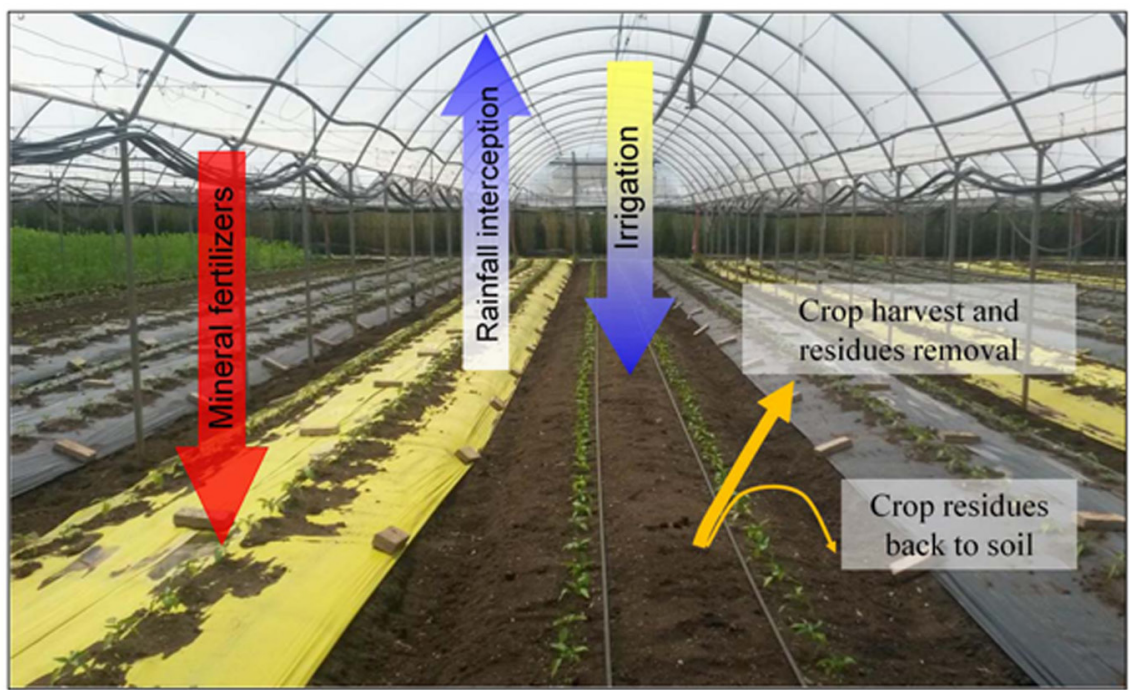

Figure 2. Schematic representation of the impact on soil quality of intensive agricultural systems under plastic cover.

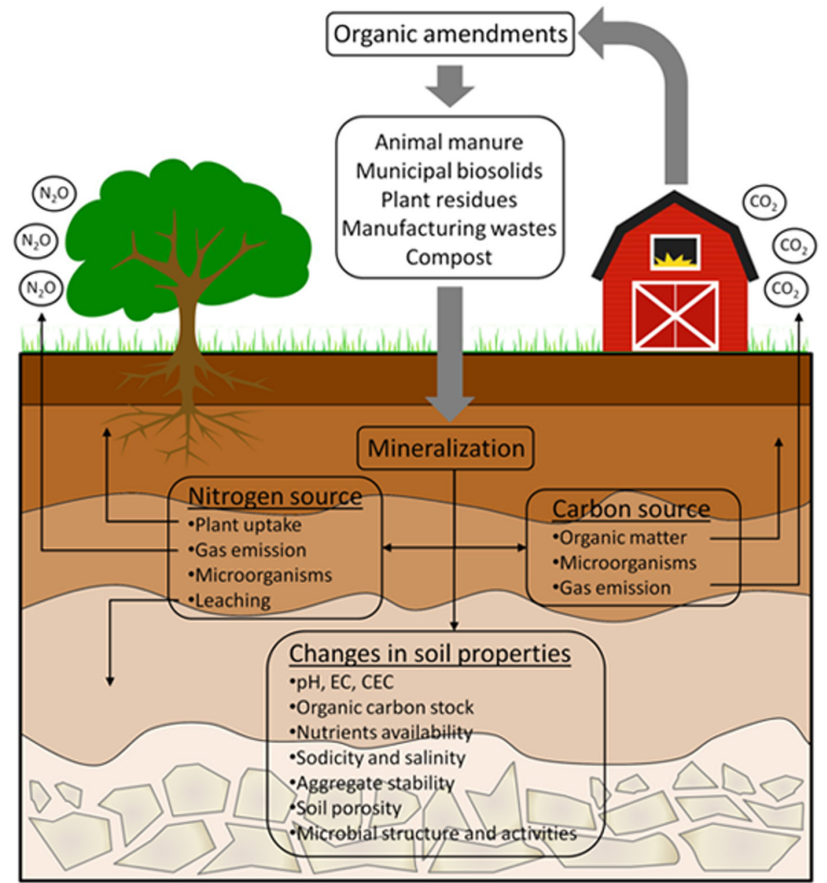

Figure 3. Schematic representation of the effect of organic amendments on soil properties by acting as a source of carbon and nitrogen. 


\subsection{Physical fertility}

As widely reported in literature, the use of organic amendments increases soil organic matter (Thangarajan et al., 2013; Khaliq and Abbasi, 2015) (Figure 3), and as consequence soil aggregate stability, water holding capacity and soil porosity (Celik et al., 2004; Leroy et al., 2008), thus improving soil quality. Scotti et al. (2013) applied Fast Field Cycling NMR relaxometry as innovative application of spectroscopic technique to soil and highlighted how the combined use of compost and wood scraps under intensive farming system, induced an increase of the soil pores size through the formation of organo-mineral aggregates which, in turn, can have positive effects on soil structure and soil aeration. The application of organic amendments such as sheep manure, cow manure, rice husk, reeds, and wheat straw increased soil aggregate stability and decreased soil bulk density (Karami et al., 2012). The latter soil property is strongly correlated to soil organic C, since the addition of organic amendments normally increases soil organic $\mathrm{C}$ and conversely decreases soil bulk density (Bauer and Black, 1994). In a longterm study in China, Zhao et al. (2009) found that farmyard manure and straw application determined a decrease of soil bulk density (1.21 and $1.18 \mathrm{Mg} \mathrm{m}^{-3}$, respectively) when compared with untreated soils $\left(1.43 \mathrm{Mg} \mathrm{m}^{-3}\right)$ due to increase in soil organic $\mathrm{C}$ and porosity.

Also organic amendments obtained from manufacturing by-products, such as biochar, can affect particle size distribution and aggregate stability. As reported in Liu et al. (2014), in agricultural soils under $40 \mathrm{tha}^{-1}$ biochar, soil water stable aggregate (> $0.25 \mathrm{~mm}$ ) in the $0-15 \mathrm{~cm}$ soil layer had a remarkable increase respect to other treatments, especially the macroaggregate with particle size larger than $>2$ $\mathrm{mm}$, suggesting that biochar incorporation into soil improves soil structure.

Sometimes, organic amendments can affect indirectly soil physical properties. Lucas et al. (2014) demonstrated that organic amendments containing high amount of bioavailable $\mathrm{C}$ derived from cellulose, can promote fungal proliferation and improve soil structure through stabilization of soil aggregates, suggesting a use of organic amendments to manipulate soil microbial community structure and to promote aggregation in soils.

\subsection{Chemical fertility}

Intensive agriculture, without organic amendments for the restoration of soil organic C stock, negatively affects soil chemical properties producing a reduction in soil $\mathrm{C}$ content, that, in turn, produces deleterious effects on soil microbial biomass, soil enzymatic activities, functional and species diversity, besides a drastic increase in soil salinity (Bonanomi et al., 2011a). A large body of empirical studies carried out in different agricultural systems demonstrated that the application of organic amendments in the form of compost, is an effective tool to recover soil organic C stock (Hargreaves et al., 2008; Zhang et al., 2015) (Figure 3). By contrast, only few studies addressed the capability of compost amendments to recover soil C stock for vegetable cultivations under plastic tunnels (Morra et al., 2010). Iovieno et al. (2009) found no significant organic $\mathrm{C}$ recovery after three consecutive years of compost amendments (up to $45 \mathrm{t} \mathrm{ha}^{-1}$ year-1), likely as a result of the rapid compost mineralization due to its relatively high biochemical quality (i.e. $\mathrm{C} / \mathrm{N}$ equal to 13). These data highlight how the recovery of soil C stock is challenging because of temperature and water availability, related to plastic cover and irrigation regime. They are not adjustable conditions 
under this specific farming system, being crucial for producing out-of-season vegetables. Therefore, a valid alternative is to identify organic amendments with specific $\mathrm{C}$ biochemical quality able to maximize stable $\mathrm{C}$ stock recovery and, at the same time, provide a continuous release of mineral nutrients satisfying crop requirements.

$\mathrm{C} / \mathrm{N}$ ratio is considered an important parameter to predict organic $\mathrm{C}$ mineralization rate and dynamical patterns of the nutrient release (Parton et al., 2007; Berg and McClaugherty, 2008). The main mechanism is related to the behaviour of saprophytic microorganisms in soil: microbes feed on organic matter requiring both organic $\mathrm{C}$ and $\mathrm{N}$ in a relatively fixed stoichiometric ratio. Organic $\mathrm{C}$ or $\mathrm{N}$ can limit microbial growth when $\mathrm{C} / \mathrm{N}$ ratio is above the threshold value of $\sim 25-30$. So, when the $\mathrm{C} / \mathrm{N}$ ratio lies above this threshold, the microbial feeding rate as well as the organic matter decomposition rate rapidly decrease, allowing long-term $\mathrm{C}$ storage. However, when an organic amendment with high $\mathrm{C} / \mathrm{N}$ ratio is incorporated into the soil, mineral $\mathrm{N}$ can be temporarily immobilized within microbial biomass, thus impairing plant growth and crop yields (Hodge et al., 2000). Indeed, a complete $\mathrm{N}$ immobilization is not acceptable under intensive farming systems where plant nutrition is tuned to match crop needs.

Therefore, a crucial step for a sustainable management of soil quality is to identify organic amendments with specific biochemical quality that effectively balance the trade-off between organic $\mathrm{C}$ stock recovery and nutrient mineralization. Recently, Scotti et al. (2015) face this issue by combining the application of high-quality (compost with a $\mathrm{C} / \mathrm{N}$ ratio equal to 13) and low-quality (wood scraps with a $\mathrm{C} / \mathrm{N}$ ratio equal to 375) organic substrates with final $\mathrm{C} / \mathrm{N}$ ratio of the mixtures equal to 15 and 25 . In this study, a 2 -years application in two different soils of a mixture composed by compost, from municipal solid waste (MSW), and wood scraps resulted in an effective, long-lasting increase of soil organic matter in average by 55 and $60 \%$. However, this stock recovery was dependent especially on soil characteristics. In general terms, when organic $\mathrm{C}$ enters the soil, the amount retained depends not only on its biochemical quality but also on its interactions with soil mineral components i.e. sand, silt, and clay fractions as well as carbonate and organic C content (Piccolo, 1996; Clough and Skjemstad, 2000). As suggested by Bonanomi et al. (2014b), in soils with characteristics far from $\mathrm{C}$ saturation, such as low organic $\mathrm{C}$ content and high clay fraction, exogenous organic matter is more easily absorbed and less exposed to microbial attack. On the other hand, in different conditions closer to $\mathrm{C}$ saturation, such as a sandy soil with high $\mathrm{C}$ content, mineral particles are less able to interact with organic compounds thus leaving more available compounds to microbial degradation.

The addition of chemical fertilizers generally leads to a rapid mineral $\mathrm{N}$ release, while organic amendments induce a slow mineral $\mathrm{N}$ release, but extended over time (Claassen and Carey, 2006). Weber et al. (2007) reported that the slow mineralization of $\mathrm{N}$ in soils under compost amendment improves not only the soil fertility, but also the conditions of organic matter mineralization. In fact, they found an increase of humic acid/fulvic acid ratio in compost amended soil which might be partly due to the original composition of humic substances in the compost, where humic acids always predominate over fulvic acids.

Although compost application could promote nitrification process, if compared with mineral fertilization it reduces $\mathrm{N}$ leaching, decreasing the possibility of nitrate groundwater contamination (Shiralipour et al., 1992; Montemurro et al., 2007). Numerous researches have been addressed on soil nutrient supply after the application of organic 
amendments. As a consequence of the application of organic amendments, which increase organic C stock, soil cation exchange capacity (CEC) increases. High values of CEC allow retaining essential nutrient cations making them available for crop productions (Bulluck Iii et al., 2002). In addition, also anions as phosphorus showed an increased solubility subsequently to organic material application (Zaccardelli et al., 2013b; Scotti et al., 2015).

One of the most worrying aspects related to the use of organic amendments, in particular to the compost from MSW, is the increase of electrical conductivity (EC) into soils (Schulz and Glaser, 2012; Bonanomi et al., 2014b), and, as consequence, the increase of salinity and sodicity that are well known for their negative effects on crop yields (Maas and Hoffman, 1977) and on soil biological activities (Rietz and Haynes, 2003) This effect can be related to both direct solubilisation of ions and mineralization of compost that releases soluble mineral nutrients. This negative effect of compost application can exacerbate the increase of soil salinity observed in soils cultivated under plastic film because the drastic rainfall restriction limits salts leaching (Bonanomi et al.,2011a). Bonanomi et al. (2014b) found that the EC values of two different soils amended with MSW compost increased, remaining well below the threshold of saline soils (i.e. 0.77 and $0.19 \mathrm{dS} \mathrm{m}^{-1}$ ), but the repeated compost application could, in the long-term, contribute to soil salinization.

\subsection{Biological fertility}

Microorganisms play a key role in decomposition of organic matter (Thangarajan et al., 2013). The main factor of soil fertility and agricultural sustainability is the diversity of soil microbial communities which govern the mineralization rate of soil organic $\mathrm{C}$ (Burauel and BaBmann, 2005) (Figure 3). Organic amendments, once added to the soil, favour the growth and diversity of microbial communities, highlighting a strong correlation between soil biological fertility and soil organic C content (Chakraborty et al., 2011). The use of soil organic amendments as compost affects soil biological properties and enzymatic activities, thanks to the readily utilizable energy sources introduced in soil (Shen and Bartha, 1997). Soil biological properties are considered good indicators of soil fertility due to their quick responses to perturbations (Nannipieri et al., 1990; Paz-Ferreiro et al., 2009). They include properties directly related to microbial biomass and activity, and to the decomposition of organic compounds, such as the activity of hydrolytic enzymes (Gil-Sotres et al., 2005).

The key role of organic matter on biological soil fertility, in intensive agriculture, was pointed out by Bonanomi et al. (2011a) who compared the biological characteristics of soils collected from different agricultural farms in a multidisciplinary approach. They found a drastic reduction of soil microbial biomass, fungal mycelium and all enzymatic activities in soils having small organic $\mathrm{C}$ content and under intensive agriculture without use of organic amendments. On the contrary, many studies provide evidence that the use of compost as organic amendment positively affects soil fertility in terms of biological and enzymatic activities (Thangarajan et al., 2013), in particular under intensive farming systems (Scotti et al., 2015).

In a study conducted for three years, in intensive farm under greenhouse conditions, Morra et al. (2010) used different doses of compost $\left(15,30,45 \mathrm{tha}^{-1}\right)$ and compost (at dose of $15 \mathrm{tha}^{-1}$ ) combined with mineral $\mathrm{N}$ fertilizer to investigate the effects of exogenous organic matter on soil enzymatic activities. They found that soil respiration, fluorescein diacetate hydrolases and phosphomonoesterase activities 
increased after compost application. The magnitude of the activity increased with compost rate and with cumulative compost amendment. In general, the broad-scale soil biological properties, such as soil respiration, fluorescein diacetate hydrolases and phosphomonoesterase activities were positively affected by compost supply, demonstrating shifts in microbial performances related to $\mathrm{C}, \mathrm{N}$ and phosphorus cycles in soil (Iovieno et al., 2009). Scotti et al. (2015) proposed compost application to soils under intensive farming systems combined with woody scraps to achieve significant changes in biological parameters. The authors found a rapid and intense boost of enzymatic activities (dehydrogenase, phosphomonoesterase and $\beta$-glucosidase) after organic amendments, especially after the second yearly amendment, demonstrating that repeated use of organic amendments should be planned to trigger microbial activity and functionality and improve consequently soil biological fertility.

The use of compost can affect soil microbial diversity, as reported by Zaccardelli et al. (2013a) who showed a clear positive effect on the number of spore-forming bacteria, with an increase directly correlated with the dose of compost. Also in stressed soil, with high saline content, the use of compost can determine an improvement of biological fertility (Lakhdar et al., 2009). Ouni et al. (2013) investigated the effects of composts, produced by MSW and palm wastes, at several doses $\left(0,50,100\right.$, and $\left.150 \mathrm{t} \mathrm{ha}^{-1}\right)$ on saline soil. They observed an increase of soil organic matter and consequently an improving of microbial biomass and several enzyme activities but the results were different in presence of the highest dose of compost $\left(150 \mathrm{tha}^{-1}\right)$, where a reduction of some activities was registered. This behaviour could be likely attributed to the potential toxic effect of the trace elements present in this particular compost (Garcia-Gil et al., 2000; Crecchio et al., 2004). Lakhdar et al. (2011) tested the use of compost from MSW and sewage sludge to enhance the fertility of degraded soils in the Mediterranean region. A clay loamy soil was amended with 0 , 40, and $80 \mathrm{t} \mathrm{ha}^{-1}$ of MSW compost or sewage sludge. A significant increase of all the measured activities (arylsulphatase, dehydrogenase, phosphomonoesterase and $\beta$-glucosidase) after 70 days at either $40 \mathrm{t} \mathrm{ha}^{-1}$ or $80 \mathrm{t} \mathrm{ha}^{-1}$ (ranged between $16 \%-160 \%$ and $10 \%-81 \%$, respectively) was registered.

In addition to traditional organic amendments, such as compost, in the last years the use of byproducts of manufacturing processes is arousing great interest. Zaccardelli et al. (2013b) proposed an alternative use of seed meals (from Brassica carinata and Helianthus annuus) as organic amendment. A positive response of the enzymatic activities (phosphomonoesterase, dehydrogenase, fluorescein diacetate hydrolases, arylsulphatase and $\beta$-glucosidase) to the addition of seed meals was detected, thus indicating a beneficial effect on soil biological fertility. Moreover, while the addition of compost, in general, determined an enhancement in microbial activity over time, seed meals produced an increase only in the short term (two months), reflecting the rate of release of nutrients. Furthermore, no effects of isothiocyanates, derived from hydrolysis of glucosinolates present in seed meal of Brassica carinata, were observed on the studied enzymatic activities.

Another alternative amendment used to restore soil organic $\mathrm{C}$ is represented by olive mill wastewaters, deriving from olive oil extraction process, whose disposal represents one of the most serious concerns for oil mills. Piotrowska et al. (2011) suggested the application of olive mill wastewaters, mainly after removal of their phenolic components, as a good strategy for restoring soils in semiarid area, characterized by shortage of organic matter. Amended soils showed, after the addition of olive 
mill wastewaters, an increase of microbial biomass because of the temporary enrichment of soil with a readily available $\mathrm{C}$ source.

\subsection{Compost and plant disease suppression}

Soilborne pathogens, including fungi and oomycetes, are among the major factors limiting the productivity of agro-ecosystems and it is often hard to control them with conventional strategies such as the use of resistant cultivars and synthetic fungicides (Martin, 2003). Application of compost has been proposed as a strategy for the management of plant diseases caused by soilborne pathogens. There are many examples of soilborne pathogens effectively controlled through the application of compost: Fusarium spp. (Borrero et al., 2004), Gaeumannomyces graminis f. sp. tritici (Tilston et al., 2002), Pythium spp. (Erhart et al., 1999), Phytophthora spp. (Szczech and Smolińska, 2001), Rhizoctonia solani (Pérez-Piqueres et al., 2006)), Sclerotinia minor (Pane et al., 2011), Verticillium dahliae (Paplomatas et al., 2005), among others.

However, the suppressiveness of compost (i.e. the capability to control plant diseases) is often in contrast with several studies that report an increase of disease incidence and severity after amendments (Tilston et al., 2002; Scheuerell et al., 2005). Termorshuizen et al. (2007), for instance, reported disease suppression in $54 \%$ of study cases, no significant suppression in $42.7 \%$, and disease enhancement in $3.3 \%$. In an extensive review of 1964 experimental studies, Bonanomi et al. (2010) found that organic amendments were suppressive on diseases in $45 \%$ of the cases, no significant in $35 \%$, but conducive in $20 \%$ (increase of the disease incidence).

Inconsistent results seriously hinder the practical application of compost for disease suppression in real agricultural systems. The critical point is that compost can be produced from a large variety of plant and animal remains, which lead to huge variation in the final chemical and microbiological properties of the compost and, then, in its disease suppressiveness. Indeed, compost is composed by very heterogeneous materials due to the diversity of composting methods, feedstock origin (e.g. municipal waste, animal manure, plant pruning, crop residues, etc.), application rate (Serra-Whittling et al., 1996a), and level of maturity (Tuitert et al., 1998). The complex relationships among these factors make difficult to predict the suppressive efficacy of compost. Substantial effort has been made during the last decade in the search for mechanisms behind disease suppression (Janvier et al., 2007), and for the identification of reliable indicators of organic amendment suppressiveness (Bonanomi et al., 2010). Compost disease suppression, differently from not composted organic wastes and crop residues, is only in a few cases due to the eradication of pathogens by fungitoxic compounds (Bonanomi et al., 2007). Induction of fungistasis and microbiostasis (Serra-Whittling et al., 1996a) and systemic resistance (Zhang et al., 1996; Pharand et al., 2002) are possible alternative, but not mutually exclusive explanations. However, very little is still known about the relationships between the chemical and microbiological characteristics of compost and disease suppression for different plant-pathogens combinations (Scheuerell et al., 2005). A promising parameter to predict compost suppressiveness is fluorescein diacetate hydrolases (FDA) activity (Chen et al., 1988), which includes different soil enzymes (non-specific esterases, proteases, lipases) related to organic $\mathrm{C}$ cycle. Other compost variables positively correlated with suppressiveness are also substrate respiration, microbial biomass, fluorescent pseudomonads and Trichoderma populations (Bonanomi et al., 2010). 


\subsection{Crops yields}

In the past century, the introduction and widespread utilization of synthetic inorganic fertilizers have allowed farmers to break the link between organic amendments and soil fertility (Hoitink and Boehm, 1999). As a consequence, organic materials, such as crop residues and manure, from essential resources became solid wastes. The reduction of the organic input progressively reduced soil organic $\mathrm{C}$ stock over time with negative effects on soil fertility (Bonanomi et al., 2011a). In this context, the use of compost has been proposed, both for conventional and biological systems of agriculture, to improve soil fertility and then crop yields (Wong et al., 1999; Ouédraogo et al., 2001; Bonanomi et al., 2014b).

Positive effect of compost on crop yields has been related to different, not mutually exclusive, mechanisms including supply of mineral nutrients (De Brito et al., 1995), improvement of soil structure and water retention capability (Serra-Wittling et al., 1996b), enhancement of soil microbial and enzymatic activities (Garcia-Gil et al., 2000), and control of soilborne pathogens (Bonanomi et al., 2010). However, in some studies negative effects of compost application on plant growth has been reported (Tiquia, 2010; Aslam and VanderGheynst, 2008). The dual, contrasting effect of compost on plant growth can be associated both to the release of essential mineral nutrients for plant nutrition and to the presence of inhibitory compounds. Two mutually non-exclusive hypotheses have been proposed to explain the inhibitory effect of compost: $\mathrm{N}$ immobilization by microbial competition (Mamo et al., 1998) and the release of phytotoxic compounds (Tiquia, 2010). The first hypothesis sustains that when $\mathrm{N}$ is available at low concentrations, as in decaying plant tissues with a high $\mathrm{C} / \mathrm{N}$ ratio, usually above the threshold value of 30 , saprophytic microbes can compete with plants for this limiting resource (Hodge et al., 2000). The second hypothesis affirms that compost can release a wide range of inhibitory compounds, including short-chain organic acids, tannins and phenols. In this regard, previous studies highlighted the importance of decomposition to understand the inhibitory impact of compost. Indeed, during decomposition process the abundance and the activity of phytotoxic compounds continuously change as a result of the chemical transformation by microorganisms, with a rapid degradation into non-toxic molecules (Bonanomi et al., 2011b). Avoiding compost phytotoxic effects is a basic step for correct management of this organic amendment. This can be achieved by optimizing application rate and by using compost opportunely stabilized during the production process (Tiquia et al., 1996).

\section{Conclusions and future research needs}

Identification of long-term sustainable management strategies is crucial to plan farming systems that effectively maintain or increase soil quality. Organic amendments, in particular compost, can represent the sustainable tool to improve soil organic $\mathrm{C}$ stock and soil fertility in intensive agriculture. Soil organic $\mathrm{C}$ storage depends on the amount of $\mathrm{C}$ inputs as well as on the amount of $\mathrm{C}$ outflows, principally regulated by temperature, water availability and quality of organic matter in soil, all factors influencing microbial activity (Parton et al., 1994). Because temperature and water availability, related to the irrigation regime, cannot be modified under plastic tunnel cultivation systems, the alternative option is to modulate organic $\mathrm{C}$ quality. In this context it is clear the need of experimental studies able to identify specific organic amendments that can maximize a stable soil organic $\mathrm{C}$ stock recovery, and, at the same time, allow a sufficient release of mineral nutrients to sustain crop yields. Moreover, to optimize 
practical applications of compost in agriculture it is necessary to assess the potential detrimental effects of such organic matter.

Compost has multiple direct and indirect effects on crop performances. Understanding the relative importance of these effects is important for the compost management, focusing on the balance between negative (i.e. phytotoxicity and $\mathrm{N}$ immobilization) and positive (i.e. nutrient release, water retention, disease suppression) effects. The challenge of future research will be the identification of specific parameters capable to predict the suppressiveness of different compost types when applied to specific plant pathogen combinations. The majority of the studies concerning compost suppressiveness has been carried out for container-produced plants such as in nurseries of horticultural and ornamental species under controlled conditions (Scheuerell et al., 2005; Termorshuizen et al., 2007; Pane et al., 2011), with no peer reviewed studies concerning compost suppressiveness for cultivations carried out in open field under plastic tunnel. Further studies are, indeed, urgently required to fill this gap in our knowledge.

\section{References}

Abiven, S., Menassero, S., Chenu, C. 2009. The effect of organic inputs over time on soil aggregate stability - a literature analysis. Soil Biol. Biochem. 41, 1-12.

Aerts, R. 1997. Climate, leaf litter chemistry and leaf litter decomposition in terrestrial ecosystems: a triangular relationship. Oikos. 79, 439-449.

Agrios, G.N. 2005. Plant diseases caused by fungi. Plant Pathology ( $5^{\text {th }}$ edition). Academic Press, San Diego, USA, 385-614 p
Aslam, D. N., VanderGheynst, J. S. 2008. Predicting phytotoxicity of compost-amended soil from compost stability measurements. Environ. Eng. Sci. 25, 72-81.

Batjes, N.H. 1996. Total carbon and nitrogen in the soils of the world. Eur. J. Soil Sci. 47, 151-163.

Bauer, A., Black, A. 1994. Quantification of the effect of soil organic matter content on soil productivity. Soil Sci. Soc. Am. J. 58, 185-93.

Berg, B., McClaugherty, C. 2008. Plant Litter: Decomposition, Humus Formation and Carbon Sequestration ( $2^{\text {nd }}$ edition). Springer-Verlag, Berlin, Heidelberg.

Bonanomi, G., Capodilupo, M., Incerti, G., Mazzoleni, S. 2014a. Nitrogen transfer in litter mixture enhances decomposition rate, temperature sensitivity, and C quality changes. Plant Soil. 381, 307-321.

Bonanomi, G., Antignani, V., Capodilupo, M., Scala, F. 2010. Identifying the characteristics of organic soil amendments that suppress soilborne plant diseases. Soil Biol. Biochem. 42, 136-144.

Bonanomi, G., Antignani, V., Pane, C., Scala, F. 2007. Suppression of soilborne fungal diseases with organic amendments. J. Plant Pathol. 89, 311-340.

Bonanomi, G., D’Ascoli, R., Antignani, V., Capodilupo, M., Cozzolino, L., Marzaioli, R., Puopolo, G., Rutigliano, F. A., Scelza, R., Scotti, R., Rao, M. A., Zoina, A. 2011a. Assessing soil quality under intensive cultivation and tree orchards in Southern Italy. Appl. Soil Ecol. 47, 187-194.

Bonanomi, G., D'Ascoli, R., Scotti, R., Gaglione, S. A., Caceres, M. G., Sultana, S., Scelza, R., Rao, M. A., Zoina, A. 2014b. Soil quality recovery and crop yield enhancement by combined application of compost and wood to vegetables grown under plastic tunnels. Agr. Ecosyst. Environ. 192, 1-7. 
Bonanomi, G., Incerti, G., Barile, E., Capodilupo, M., Antignani, V., Mingo, A., Lanzotti, V., Scala, F., Mazzoleni, S. 2011b. Phytotoxicity, not nitrogen immobilization, explains plant litter inhibitory effects: evidence from solid-state ${ }^{13} \mathrm{C}$ NMR spectroscopy. New Phytol. 191, 1018-1030.

Bonanomi, G., Incerti, G., Giannino, F., Mingo, A., Lanzotti, V., Mazzoleni, S. 2013. Litter quality assessed by solid state ${ }^{13} \mathrm{C}$ NMR spectroscopy predicts decay rate better than $\mathrm{C} / \mathrm{N}$ and Lignin $/ \mathrm{N}$ ratios. Soil Biol. Biochem. 56, 40-48.

Borrero, C., Trillas, M. I., Ordovás, J., Tello, J. C., Avilés, M. 2004. Predictive factors for the suppression of Fusarium wilt of tomato in plant growth media. Phytopathology. 94, 1094-1101.

Bulluck Iii, L. R., Brosius, M., Evanylo, G. K., Ristaino, J. B. 2002. Organic and synthetic fertility amendments influence soil microbial, physical and chemical properties on organic and conventional farms. Appl. Soil Ecol. 19, 147-60.

Burauel, P., BaBmann, F. 2005. Soils as filter and buffer for pesticides-experimental concepts to understand soil functions. Environ. Pollut. 133, 11-6.

Celik, I., Ortas, I., Kilic, S. 2004. Effects of compost, mycorrhiza, manure and fertilizer on some physical properties of a Chromoxerert soil. Soil Tillage Res. 78, 59-67.

Chakraborty, A., Chakrabarti, K., Chakraborty, A., Ghosh, S. 2011. Effect of long-term fertilizers and manure application on microbial biomass and microbial activity of a tropical agricultural soil. Biol. Fertil. Soils. 47, 227-33.

Chen, Q., Zhang, X., Zhang, H., Christie, P., Li, X., Horlacher, D., Liebig, H. P. 2004. Evaluation of current fertilizer practice and soil fertility in vegetable production in the Beijing region. Nutr. Cycl. Agroecosys. 69, 51-58.
Chen, W., Hoitink, H. A. J., Madden, L. V. 1988. Microbial activity and biomass in container media for predicting suppressiveness to damping-off caused by Pythium ultimum. Phytopathology. 78, 1447-1450.

Claassen, V. P., Carey, J. L. 2006. Comparison of slow-release nitrogen yield from organic soil amendments and chemical fertilizers and implications for regeneration of disturbed sites. Land Degrad. Dev. 18, 119-132.

Clough, A., Skjemstad, J. O. 2000. Physical and chemical protection of soil organic carbon in three agricultural soils with different contents of calcium carbonate. Austr. J. Soil Res. 38, 10051016.

Crecchio, C., Curci, M., Mininni, R., Ricciuti, P., Ruggiero, P. 2004. Effects of municipal solid waste compost amendments on soil enzyme activities and bacterial genetic diversity. Soil Biol. Biochem. 36, 1595-1605.

De Brito, A. M., Gagne, S., Antoun, H. 1995. Effect of compost on rhizosphere microflora of the tomato and on the incidence of plant growth-promoting rhizobacteria. Appl. Environ. Microb. 61, 194199.

Donn, S., Wheatley, R. E., McKenzie, B. M., Loades, K. W., Hallett, P. D. 2014. Improved soil fertility from compost amendment increases root growth and reinforcement of surface soil on slope. Ecol. Eng. 71, 458-465.

Doran, J. W., Parkin T. B. 1994. Defining and assessing soil quality. Defining soil quality or a sustainable environment. SSSA Inc, Madison, USA.

Erhart, E., Burian, K., Hartl, W., Stich, K. 1999. Suppression of Pythium ultimum by biowaste composts in relation to compost microbial biomass, activity and content of phenolic compounds. J. Phytopathol. 147, 299-305. 
Eurostat 2015. Statistics Explained (http://ec.europa. eu/eurostat/statistics-explained/). (accessed March 2015).

Fontaine, S., Barot, S., Barré, P., Bdioui, N., Mary, B., Rumpel, C. 2007. Stability of organic carbon in deep soil layers controlled by fresh carbon supply. Nature. 450, 277-280.

Garcia-Gil, J. C., Plaza, C., Soler-Rovira, P., Polo, A. 2000. Long-term effects of municipal solid waste compost application on soil enzyme activities and microbial biomass. Soil Biol. Biochem. 32, 19071913.

Gil-Sotres, F., Trasar-Cepeda, C., Leirós, M. C., Seoane, S. 2005. Different approaches to evaluate soil quality using biochemical properties. Soil Biol. Biochem. 37, 877-887.

Goss, M. J., Tubeileh, A., Goorahoo, D. 2013. A review of the use of organic amendments and the risk to human health. Adv. Agron. 120, 275-379.

Halvorson, A. D., Wienhold, B. J., Black, A. L. 2002. Tillage, nitrogen, and cropping system effects on soil carbon sequestration. Soil Sci. Soc. Am. J. 66, 906-912.

Hargreaves, J. C., Adl, M. S., Warman, P. R. 2008. A review of the use of composted municipal solid waste in agriculture. Agr. Ecosyst. Environ. 123, $1-14$.

Hector, A., Schmid, B., Beierkuhnlein, C., Caldeira, M.C., Diemer, M., Dimitrakopoulos, P.G., Finn, J.A., Freitas, H., Giller, P.S., Good, J., Harris, R., Högberg, P., Huss-Danell, K., Joshi, J., Jumpponen, A., Körner, C., Leadley, P. W., Loreau, M., Minns, A., Mulder, C.P.H., O’Donovan, G., Otway, S. J., Pereira, J.S., Prinz, A., Read, D.J., Scherer-Lorenzen, M., Schulze, E.-D., Siamantziouras, A..S.D., Spehn, E. M., Terry, A. C., Troumbis, A. Y., Woodward, F. I., Yachi, S., Lawton, J.H. 1999. Plant diversity and productivity experiments in European grasslands. Science. 286, 1123-1127.

Hodge, A., Robinson, D., Fitter, A.H. 2000. Are microorganisms more effective than plants at competing for nitrogen? Trends Plant Sci. 5, 304308 .

Hoitink, H. A. J., Boehm, M. J. 1999. Biocontrol within the context of soil microbial communities: a substrate-dependent phenomenon. Ann. Rev. Phytopathol. 37, 427-446.

Iovieno, P., Morra, L., Leone, A., Pagano, L., Alfani, A. 2009. Effect of organic and mineral fertilizers on soil respiration and enzyme activities of two Mediterranean horticultural soils. Biol. Fert. Soils. 45, 555-561.

Janvier, C., Villeneuve, F., Alabouvette, C., EdelHermann, V., Mateille, T., Steinberg, C. 2007. Soil health through soil disease suppression: Which strategy from descriptors to indicators? Soil Biol. Biochem. 39, 1-23.

Ju, X. T., Kou, C. L., Christie, P., Dou, Z. X., Zhang, F. S. 2007. Changes in the soil environment from excessive application of fertilizers and manure to two contrasting intensive cropping systems on the North China Plain. Environ. Pollut. 145, 497-506.

Karami, A., Homaee, M., Afzalinia, S., Ruhipour, H., Basirat, S. 2012. Organic resource management: impacts on soil aggregate stability and other soil physico-chemical properties. Agric. Ecosyst. Environ. 148, 22-8.

Khaliq, A., Abbasi, M.K. 2015. Improvements in the physical and chemical characteristics of degraded soils supplemented with organic-inorganic amendments in the Himalayan region of Kashmir, Pakistan. Catena. 126, 209-219.

Knops, J.M., Tilman, D. 2000. Dynamics of soil nitrogen and carbon accumulation for 61 years after agricultural abandonment. Ecology. 81, 8898. 
Lakhdar, A.. Scelza, R., Achiba, W. B., Scotti, R., Rao, M. A., Jedidi, N., Abdelly, C., Gianfreda, L. 2011. Effect of municipal solid waste compost and sewage sludge on enzymatic activities and wheat yield in a clayey-loamy soil. Soil Sci. 176, 15-21.

Lakhdar, A., Rabhi, M., Ghnaya, T., Montemurro, F., Jedidi, N., Abdelly, C. 2009. Effectiveness of compost use in salt-affected soil. J. Hazard. Mater. 171, 29-37.

Lamont, W. J. 2009. Overview of the use of high tunnels worldwide. HortTechnology. 19, 25-29.

Leroy, B. L. M., Herath, H. M. S. K., Sleutel, S., De Neve, S., Gabriels, D., Reheul, D., Moens, M. 2008. The quality of exogenous organic matter: short-term effects on soil physical properties and soil organic matter fractions. Soil Use Manag. 24, 139-47.

Liu, Z., Chen, X., Jing, Y., Li, Q., Zhang, J., Huang, Q. 2014. Effects of biochar amendment on rapeseed and sweet potato yields and water stable aggregate in upland red soil. Catena. 123, 45-51.

Loreau, M., Naeem, S., Inchausti, P., Bengtsson, J., Grime, J. P., Hector, A., Hooper, D. U., Huston, M. A., Raffaelli, D., Schmid, B., Tilman, D., Wardle, D. A. 2001. Biodiversity and ecosystem functioning: current knowledge and future challenges. Science. 294, 804-808.

Lucas, T. S., D’Angelo, E. M., Williams, M. A. 2014. Improving soil structure by promoting fungal abundance with organic soil amendments. Appl. Soil Ecol. 75, 13-23.

Mäder, P., Fließbach, A., Dubois, D., Gunst, L., Fried, P., Niggli, U. 2002. Soil fertility and biodiversity in organic farming. Science 296, 1694-1697.

Mamo, M., Rosen, C. J., Halbach, T. R., Moncrief, J. F. 1998. Corn yield and nitrogen uptake in sandy soils amended with municipal solid waste compost. J. Prod. Agric. 11, 469-475.
Martin, F. N. 2003. Development of alternative strategies for management of soilborne pathogens currently controlled with methyl bromide. Annu. Rev. Phytopathol. 41, 325-350.

Maas, E. V., Hoffman, G. J. 1977. Crop salt tolerancecurrent assessment. J. Irrig. Drain. 103, 115-134.

Montemurro, F., Maiorana, M., Convertini, G., Ferri, D. 2007. Alternative sugar beet production using shallow tillage and municipal solid waste fertilizer. Agron. Sustain. Dev. 27, 129-137.

Morra, L., Pagano, L., Iovieno, P., Baldantoni, D., Alfani, A. 2010. Soil and vegetable crop response to addition of different levels of municipal waste compost under Mediterranean greenhouse conditions. Agron. Sustain. Dev. 30, 701-709.

Nannipieri, P., Ceccanti, B., Grego, S. 1990. Ecological Significance of Biological Activity in Soil. Soil Biochemistry. Vol. 6. Marcel Dekker, New York, USA, 293-355 p.

Needelman, B. A. 2013. What Are Soils? Nat. Educ. Knowl. 4, 2.

Ouédraogo, E., Mando, A., Zombré, N. P. 2001. Use of compost to improve soil properties and crop productivity under low input agricultural system in West Africa. Agr. Ecosyst. Environ. 84, 259266.

Ouni, Y., Lakhdar, A., Scelza, R., Scotti, R., Abdelly, C., Barhoumi, Z., Rao, M. A. 2013. Effects of two composts and two grasses on microbial biomass and biological activity in a salt-affected soil. Ecol. Eng. 60, 363-369.

Pane, C., Celano, G., Piccolo, A., Villecco, D., Spaccini, R., Palese, A.M., Zaccardelli, M. 2015. Effects of on-farm composted tomato residues on soil biological activity and yields in a tomato cropping system. Chem. Biol. Technol. Agric. 2, 4. 
Pane, C., Spaccini, R., Piccolo, A., Scala, F., Bonanomi, G. 2011. Compost amendments enhance peat suppressiveness to Pythium ultimum, Rhizoctonia solani and Sclerotinia minor. Biol. Control. 56, 115-124.

Paplomatas, E. J., Tjamos, S. E., Malandrakis, A. A., Kafka, A. L., Zouvelou, S. V. 2005. Evaluation of compost amendments for suppressiveness against Verticillium wilt of eggplant and study of mode of action using a novel Arabidopsis pathosystem. Eur. J. Plant Pathol. 112, 183-189.

Pardossi, A., Tognoni, F., Incrocci, L. 2004. Mediterranean greenhouse technology. Chron. Horticult. 44, 28-34.

Park, J. H., Lamb, D., Paneerselvam, P., Choppala, G., Bolan, N., Chung, J. W. 2011. Role of organic amendments on enhanced bioremediation of heavy metal(loid) contaminated soils. J. Hazard. Mater. 185, 549-574.

Parton, W., Silver, W. L., Burke, I. C., Grassens, L., Harmon, M. E., Currie, W. S., King, J. Y., Adair, E. C., Brandt, L. A., Hart, S. C., Fasth, B. 2007. Global-scale similarities in nitrogen release patterns during long-term decomposition. Science. 315, 361-364.

Parton, W. J., Ojima, D. S., Cole, C. V., Schimel, D. S. 1994. A general model for soil organic matter dynamics: sensitivity to litter chemistry, texture, and management. Quantitative modelling of soil forming processes. SSSA Special Publication 39, Madison, USA, 147-167 p.

Paustian, K., Six, J., Elliott, E. T., Hunt, H. W. 2000. Management options for reducing $\mathrm{CO}_{2}$ emissions from agricultural soils. Biogeochemistry. 48, 147-163.
Paz-Ferreiro, J., Trasar-Cepeda, C., Leirós, M. C., Seoane, S., Gil-Sotres, F. 2009. Biochemical properties in managed grassland soils in a temperate humid zone: modifications of soil quality as a consequence of intensive grassland use. Biol. Fertil. Soils. 45, 711-722.

Pérez-Piqueres, A., Edel-Hermann, V., Alabouvette, C., Steinberg, C. 2006. Response of soil microbial communities to compost amendments. Soil Biol. Biochem. 38, 460-470.

Pharand, B., Carisse, O., Benhamou, N. 2002 Cytological aspects of compost-mediated induced resistance against Fusarium crown and root rot in tomato. Phytopathology. 92, 424-438.

Piccolo, A., 1996. Humus and Soil Conservation Humic Substances in Terrestrial Ecosystems. Elsevier, Amsterdam, 225-264 p.

Piotrowska, A., Rao, M. A., Scotti, R., Gianfreda, L. 2011. Changes in soil chemical and biochemical properties following amendment with crude and dephenolized olive mill waste water (OMW). Geoderma. 161, 8-17.

Rietz, D. N., Haynes, R. J. 2003. Effects of irrigationinduced salinity and sodicity on soil microbial activity. Soil Biol. Biochem. 35, 845-854.

Ros, M., Hernandez, M.T., Garcìa, C. 2003. Soil microbial activity after restoration of a semiarid soil by organic amendments. Soil Biol. Biochem. $35,463-469$.

Scarascia-Mugnozza, G., Sica, C., Russo, G. 2011. Plastic materials in European agriculture: actual use and perspectives. J. Agr. Eng. 42, 15-28.

Scheuerell, S.J., Sullivan, D.M., Mahaffee, W.F. 2005 Suppression of seedling damping-off caused by Pythium ultimum, P. irregulare, and Rhizoctonia solani in container media amended with a diverse range of Pacific Northwest compost sources. Phytopathology. 95, 306-315. 
Schulz, H., Glaser, B. 2012. Effects of biochar compared to organic and inorganic fertilizers on soil quality and plant growth in a greenhouse experiment. J. Plant. Nutr. Soil Sci. 175, 410-422.

Scotti, R., Conte, P., Berns, A. E., Alonzo, G., Rao, M. A. 2013. Effect of organic amendments on the evolution of soil organic matter in soils stressed by intensive agricultural practices. Curr. Org. Chem. 17, 2998-3005.

Scotti, R., D’Ascoli, R., Bonanomi, G., Caceres, M. G., Sultana, S., Cozzolino, L., Scelza, R., Zoina, A., Rao, M. A. 2015. Combined use of compost and wood scraps to increase carbon stock and improve soil quality in intensive farming systems. Eur. J. Soil Sci. doi: 10.1111/ejss. 12248

Serra-Wittling, C., Houot, S., Alabouvette, C. 1996a. Increased soil suppressiveness to Fusarium wilt of flax after addition of municipal solid waste compost. Soil Biol. Biochem. 28, 1207-1214.

Serra-Wittling, C., Houot, S., Barriuso, E. 1996b. Modification of soil water retention and biological properties by municipal solid waste compost. Compost Sci. Util. 4, 44-52.

Shen, J., Bartha, R. 1997. Priming effect of glucose polymers in soil-based biodegradation tests. Soil Biol. Biochem. 29, 1195-1198.

Shiralipour, A., McConnell, D. B., Smith, W. H. 1992. Uses and benefits of MSW compost: a review and an assessment. Biomass Bioenerg. 3, 267-279.

Sullivan, P. 2003. Overview of cover crops and green manures: fundamentals of sustainable agriculture.

Szczech, M., Smolińska, U. 2001. Comparison of suppressiveness of vermicomposts produced from animal manures and sewage sludge against Phytophthora nicotianae Breda de Haan var. nicotianae. J. Phytopathol. 149, 77-82.
Termorshuizen, A. J., van Rijn, E., van der Gaag, D. J., Alabouvette, C., Chen, Y., Lagerlöf J., Malandrakis, A. A., Paplomatas, E. J., Rämert, B., Ryckeboer, J., Steinberg, C., Zmora-Nahum, S. 2007. Suppressiveness of 18 composts against 7 pathosystems: Variability in pathogen response. Soil Biol. Biochem. 38, 2461-2477.

Thangarajan, R., Bolan, N. S., Tian, G., Naidu, R., Kunhikrishnan, A. 2013. Role of organic amendment application on greenhouse gas emission from soil. Sci. Total Environ. 465, 7296.

Tian, G., Kang, B. T., Brussaard, L. 1992. Biological effects of plant residues with contrasting chemical compositions under humid tropical conditionsdecomposition and nutrient release. Soil Biol. Biochem. 24, 1051-1060.

Tilman, D., Cassman, K. G., Matson, P. A., Naylor, R., Polasky, S. 2002. Agricultural sustainability and intensive production practices. Nature. 418, 671-677.

Tilston, E. L., Pitt, D., Groenhof, A. C. 2002. Composted recycled organic matter suppresses soil-borne diseases of field crops. New Phytol. 154, 731-740.

Tiquia, S.M. 2010. Reduction of compost phytotoxicity during the process of decomposition. Chemosphere. 79, 506-512.

Tiquia, S.M., Tam, N.F.Y., Hodgkiss, I. J. 1996. Effects of composting on phytotoxicity of spent pig-manure sawdust litter. Environ. Pollut. 93, 249-256.

Tuitert, G., Szczech, M., Bollen, G.J. 1998. Suppression of Rhizoctonia solani in potting mixtures amended with compost made from organic household waste. Phytopathology. 88, 764-773. 
Tuomela, M., Vikman, M., Hatakka, A., Itävaara, M. 2000. Biodegradation of lignin in a compost environment: a review. Bioresource Technol. 72, 169-183.

Weber, J., Karczewska, A., Drozd, J., Licznar, M., Licznar, S., Jamroz, E., Kocowicz, A. 2007. Agricultural and ecological aspects of a sandy soil as affected by the application of municipal solid waste composts. Soil Biol. Biochem. 39, 1294-1302.

Wong, J. W. C., Ma, K. K., Fang, K. M., Cheung, C. 1999. Utilization of a manure compost for organic farming in Hong Kong. Bioresource Technol. 67, 43-46.

Worldometers 2015. Real-time statistics (http://www. worldometers.info/it/) (accessed March 2015).

Xiong, Y., Zeng, H., Xia, H., Guo, D. 2014. Interactions between leaf litter and soil organic matter on carbon and nitrogen mineralization in six forest litter-soil systems. Plant Soil. 379, 217 229.
Zaccardelli, M., De Nicola, F., Villecco, D., Scotti, R. 2013a. The development and suppressive activity of soil microbial communities under compost amendment. J. Soil Sci. Plant Nutr. 13, 730-742.

Zaccardelli, M., Villecco, D., Celano, G., Scotti, R. 2013b. Soil amendment with seed meals: Short term effects on soil respiration and biochemical properties. Appl. Soil Ecol. 72, 225-231.

Zhang, H., Ding, W., Yu, H., He, X. 2015. Linking organic carbon accumulation to microbial community dynamics in a sandy loam soil: result of 20 years compost and inorganic fertilizers repeated application experiment. Biol. Fert. Soils. 51, 137-150.

Zhang, W., Dick, W. A., Hoitink, H. A. J. 1996. Compost-induced systemic acquired resistance in cucumber to Pythium root rot and anthracnose. Phytopathology. 86, 1066-1070.

Zhao, Y., Wang, P., Li, J., Chen, Y., Ying, X., Liu, S. 2009. The effects of two organic manures on soil properties and crop yields on a temperate calcareous soil under a wheat-maize cropping system. Eur. J. Agron. 31,36-42. 